УДК 373.2.015.31

DOI:

Оксана Гевко, кандидат педагогічних наук, доиент кафедри загальної педагогіки та дошкільної освіти Дрогобииького державного педагогічного університету імені Івана Франка

\title{
ПЕДАГОГІЧНІ УМОВИ ФОРМУВАННЯ ТВОРЧИХ ЗДІБНОСТЕЙ ДІТЕЙ СТАРШОГО ДОШКІЛЬНОГО ВІКУ
}

У статті розглянуто психолого-педагогічні підходи до визначення поняття творчості, формування творчих здібностей особистості. Проведено аналіз теоретико-методичних досліджень вітчизняних та зарубіжних фахівиів та визначено критерії наявності творчих здібностей дітей старшого дошкільного віку. Обтрунтовано педагогічні умови для творчого розвитку старших дошкільників: створення комфортної психологічної обстановки; організачія спостережень, проведення творчих бесід, ігрових завдань та задач, розвивальних ситуацій; підвищення компетентності педагогів та батьків. Визначено програму організації навчально-виховного прочесу у закладах дошкільної освіти для формування творчих здібностей у старших дошкільників, введення у програму спеціальних занять з логіко-математичного розвитку, мовленнєвого розвитку, малювання, художньої праці, музики, танців, ознайомлення з природним середовищем.

Ключові слова: творчість; креативність; творчі здібності дітей старшого дошкільного віку.

Jim. 4.

Oksana Hevko, Ph.D.(Pedagogy), Associate Professor of the General Pedagogy and Preschool Education Department, Drohobych Ivan Franko State Pedagogical University

\section{PEDAGOGICAL CONDITIONS OF CREATIVE ABILITIES FORMATION OF OLDER PRE-SCHOOL-AGE CHILDREN}

The article deals with psychological and pedagogical approaches to defining the concept of creativityand the formation of creative abilities of the individual. The analysis of the theoretical and methodological researches of domestic and foreign specialists is carried out and the criteria of availability of creative abilities of children of senior preschool age are determined: activity, initiative of personality of preschooler in thinking, activity, communication; presence of certain inclinations, abilities, interests, creative imagination; heuristics; imagination; sufficient level of vital competence; flexibility of thinking; independence; improvisation. The pedagogical conditions for creative development of senior preschool children are substantiated: creation of comfortable psychological environment; organizing observations, conducting creative conversations, playing tasks and assignments, developmental situations; raising the competence of teachers and parents. The program of organization of educational process in pre-school educational establishments for the formation of creative abilities of senior preschool children is defined: the introduction of special classes in logic and mathematical development, speech development, drawing, art work, music, dance, familiarization with the natural environment with the application of creative tasks character; directing the subject, story-role, stage performances of senior preschoolers to develop creative abilities; the use of integrated special tasks and games to develop the creative skills of older preschoolers; work with parents and educators, as well as self-improvement of educators.

Keywords: creativity; creative work; creativity skills; older pre-school-age children.

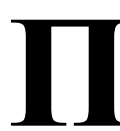

остановка проблеми. Сучасний інтенсивний розвиток і якісні перетворення у сфері освіти, спрямовані на виховання творчої особистості, що зумовлює необхідність переосмислення змісту діяльності усіх соціальних інститутів, зокрема, закладів дошкільної освіти, у яких закладаються основи для розвитку творчого потенціалу особистості, іiі інтелектуального, духовного та морального розвитку.

Соціально-педагогічна система освіти, в тому числі й система дошкільної освіти потребує інноваційних змін у змісті, умовах та формах організації педагогічного процесу, який забезпечує дитині дошкільного віку можливість саморозвитку, самовизначення та соціалізації. Особливістю сучасних технологій дошкільної освіти є формування у дошкільників творчого ставлення до життя, активізація їх особистісного потенціалу, розвиток творчої уяви, мислення, самовияву та самовираження [2, 17].

Особливого значення на сучасному етапі розвитку освіти набуває творчий розвиток особистості, інтелектуальний розвиток, розвиток iї талантів, здібностей, про що регламентовано у нормативно-правових документах закладів дошкільної освіти України, зокрема у Базовому компоненті дошкільної освіти як Державному стандарті дошкільної освіти України.

У ньому акцентується увага на результативності 
процесу та продуктів творчої діяльності дошкільників, що має включати здатність орієнтуватися в розмаїтті властивостей предметів, опануванні навичок практичної діяльності, їх емоційно-ціннісному ставлення до власної діяльності, позитивну мотивацію досягнень, вияв інтересу до об'єктів, явищ і форм художньопродуктивної діяльності, культури споживання.

Реалізація даного процесу має включати розвиток особистості, готової до творчого перетворення різних сфер соціального життя.

Аналіз останніх досліджень і публікацій. На сучасному етапі існують різні підходи до визначення понять “творчість” та “креативність”, окреслення ознак креативності та творчості, зокрема, для багатьох науковців, таких якЛ. Артемова, Л.Випотський, Т.Дугкевич,Д.Ельконін,О.Запорожець, Г. Костюк, Н. Меншинська, Р. Нємов та інших властиве ототожнення поняття "творчість" 3 поняттям “креативність”. У дослідженнях А.В.Брушлінського,П.К.Енгельмейєра, Я.О.Пономарьова та інших креативність слід розглядати як процес творчого мислення. Багато науковців розглядають креативність як сукупність особливостей психіки, які забезпечують продуктивні перетворення в діяльності людини, що реалізується в процесі творчості та формується залежно від умов, в яких вона протікає (Д. Гілфорд, Е. Еріксон, К. Роджерс, Е. Торренс, Д. Треффінгер, Е. Фромм та інші).

Г.С. Костюк, Н.О. Менчинська, Р.С. Нємов, Я.А. Пономарьов, наголошують, що креативність характеризується наявністю таких рис особистості, як ініціативність, творчий потенціал, творча активність, творча спрямованість, імпровізаційність.

Проблему творчості дітей, розвитку їх креативних здібностей, творчого мислення розглядали науковці різних галузей. Д. Богоявленська, А. Козирєва, Дж. Гілфорд, П. Торренс та інші у своїх дослідженнях розглядають специфічні особливості творчих здібностей, серед яких виділяють оригінальність, швидкість, пластичність, гнучкість. Розробка та апробація практичних методів розвитку творчих здібностей у процесі навчання була здійснена у дослідженнях I. Лернера, Л. Занкова, О. Матюшкіна, та ін. Дослідження творчості дітей, а також визначення критеріїв оцінки їірезультатів зроблено Л. Артемовою, А.Богуш,Н.Гавриш,О.Кононк,,К.Кругій,Н.Кудикіною, Т.Піроженко, З. Плохій, Т. Поніманською, О. Савченко, Г. Тарасенко та ін.

Розробка та апробація практичних методів розвитку творчих здібностей у процесі навчання була здійснена у дослідженнях I. Лернера, Л. Занкова, О. Матюшкіна, та ін.
Сучасні науковці вважають, що бути творчою людиною означає в усе навколо вносити своє, оригінальне, неповторне, унікальне та індивідуальне, тобто уміння виходити за традиційні уявлення та установки, застосовуючи власне фантазування, мислення та уявлення. Дослідниця С. Сисоєва наголошує, що найважливішим завданням всіх світових освітніх систем є забезпечення творчого розвитку особистості [3, 12].

Метою дослідження $\epsilon$ обгрунтування педагогічних умов формування творчих здібностей дошкільників та окреслення можливостей використання результатів дослідження у науковопрактичній діяльності педагога.

Виклад основного матеріалу. У соціальногносеологічному аспекті творчість відрізняється від стереотипної, шаблонної діяльності, що виключає повторення відомого, раніше здобутого $[4,88]$. Творчість може проявлятися в освоєнні дійсності, науковій, технічній, естетичній, художній, хореографічній діяльності, в особистій діяльності, стосунках із навколишнім середовищем.

Сучасними науковцями, педагогами, психологами поняття “творчість” трактується як: форма людської активності, яка створює нові підходи, виконує перетворювальну функцію, змінює суттєвий порядок (В. Дружинін, О. Матюшкін); процес людської діяльності, результатом якого $є$ нові матеріальні та духовні цінності в єдності з розвитком властивостей особистості(Л. Виготський,В.Моляко, О. Тихомиров); механізм розвитку особистості, суспільства, середовища й культури загалом, подолання певних стереотипів і шаблонів, суб'єктне, ціннісне утворення, відкриття невідомого, створення чогось нового, (А. Шумілін, Я. Пономарьов); прагнення людини до реалізації іiі унікального змісту життя, потреба в самовизначенні, самовдосконаленні, самоактуалізації, самореалізації, що має суттєвий вплив на формування особистості, допомагає їй розкрити власний потенціал, реалізувати себе як унікальну творчу особистість (А. Маслоу, К. Роджерс, О. Леонтьєв). Також науковці розглядають її як розумову і практичну діяльність, яка сприяє створенню оригінальних, неповторних цінностей, виявленню нових закономірностей, властивостей, фактів [1, 71], а також як діяльність вдосконалення, розвитку, що пройнята елементами нового, містить певне збагачення вже відомого.

Творчим людям притаманні висока чутливість, цілісне бачення проблеми, здатність бачити те, чого не бачать інші, певні особливості пам'яті, які проявляються в легкому та деталізованому 
засвоєнні основної інформації й швидкому забуванні непотрібного; швидке запам'ятовування маловживаних або маловідомих слів, фактів, образів; здатність помічати й розуміти те, що іншими вважається звичним, усвідомлення багатозначності слів, відчуття певних підтекстів. Творчі особистості відрізняються швидкістю, оригінальністю, гнучкістю, відкритістю мислення, вмінням узагальнювати не пов'язані між собою явища, факти.

Важливими умовами творчості є здатність знаходження й вирішення проблем, спроможність до прийняття нових ідей, рішень, сміливість, ініціативність, незалежність суджень та оцінок, самокритичність та здатність до самовдосконалення.

Передумовою творчості, прояву творчих здатностей дітей дошкільного віку є креативність, тобто потенційна здібність до різнобічних почуттів, мислення, вчинків, дій. Креативність, як індивідуальна особливість дитини, виявляється у здатності відмовитися від стереотипних способів мислення у вирішенні побутових, навчальних, соціально-моральних проблем [1, 349].

Першочерговим завданням усіх можливих педагогічних впливів на дитину старшого дошкільного віку є розвиток у неї творчих здібностей і ми вбачаємо виявленні, знаходженні і формуванні вихователями у закладі дошкільної освіти унікальних особистих здібностей дошкільників, розкриття у них творчих потенцій власного “я”, удосконалення їх природних задатків, нахилів та здібностей через організацію навчально-виховного процесу у закладах дошкільної освіти, зміст і завдання якого мають сприяти створенню умов для формування творчої індивідуальності, стимулювати прояв творчих можливостей дітей старшого дошкільного віку. Організація педагогами навчально-виховного процесу має враховувати творчі нахили та здібності старших дошкільників, грунтуватись на глибокому знанні вихователями індивідуальних особливостей, духовного світу кожного вихованця.

Враховуючи ці особливості, можна виділити важливі елементи формування творчих здібностей дітей старшого дошкільного віку, зокрема: створення сприятливого розвивального середовища; діяльність; використання варіативних технологій навчання та виховання; спільний контакт $з$ однолітками; розроблення разом 3 вихователями індивідуальних програм розвитку, які виявляють здібності; правильний добір завдань, вправ та ігор; сприяння організації роботи гуртків за уподобаннями (художні, музичні, танцювальні, з розвитку логічного мислення, комп'ютерні, з вивчення іноземних мов тощо); забезпечення обладнанням у групових кімнатах куточків діяльності за уподобанням (центрів); впровадження елементів теорії розв'язання винахідницьких завдань для активізації розумової діяльності і творчих можливостей дошкільнят; залучення старших дошкільників до спеціальних занять для розвитку комунікабельності та зняття тривожності, страхів, запобігання неврозам; створення умов для проведення профілактичних і оздоровчих заходів; забезпечення гнучкого режиму дня для профілактики психологічного дискомфорту, здійснення індивідуального підходу до кожної дитини старшого дошкільного віку, врахування інтересів сім'ї; систематичне проведення спостереження у групах, аналіз результатів діяльності старших дошкільників 3 метою виявлення їх інтересів та нахилів.

Ефективність упровадження технології формування творчих здібностей дітей дошкільного віку залежить від низки взаємообумовлених педагогічних умов, тому ми рекомендували вихователям для творчого розвитку старших дошкільників створення педагогічних умов формування творчих здібностей:

- ранній інтелектуальний та фізичний розвиток дошкільників;

- створення комфортної психологічної обстановки, що випереджує розвиток старшого дошкільника, заохочення вихователів прагнень дошкільників до творчості;

- організація спостережень, проведення творчих бесід, створення у навчально-виховному процесі виховних та ігрових розвивальних ситуацій;

- застосування серії спеціальних ігрових завдань у процесі різних видів діяльності;

- стимулювання старших дошкільників до вирішення завдань та задач, які потребують максимального напруження сил та можливостей;

- надання дошкільникам волі у виборі діяльності, тривалості занять, чергуванні та зміні видів діяльності;

- доброзичлива допомога

- допомога в разі потреби, а не підказка вихователів;

- впровадження спеціальної роботи з батьками, спрямованої на підвищення їхньої компетентності з питань розвитку винахідливості дитини в умовах родинного виховання;

- застосування методів, спрямованих на підвищення компетентності педагогів та батьків з проблеми розвитку творчих здібностей старших дошкільників в умовах закладу дошкільної освіти: бесід, консультацій, диспутів, семінарів-тренінгів, 
“круглих столів”, конкурсів, спільних виховних заходів із старшими дошкільниками;

- використання методу спроб і помилок, методу фокальних об'єктів, методу фантастичної аналогії, методу функціонально-вартісного аналізу тощо у роботі із старшими дошкільниками;

- використання ігрової діяльності для розвитку творчих розвиток творчих здібностей, творчої уяви дітей старшого дошкільного віку;

- використання мовленнєво-творчого розвитку, роботи з казкою для розвитку творчих здібностей дітей старшого дошкільного віку;

- розвиток творчих здібностей у старших дошкільників засобами образотворчого, музичного, хореографічного та театрального мистецтва;

- створення спеціально-організованих виховних ситуацій та пропонування старшими дошкільниками виходу з них;

- психологічні вправи на розвиток творчого мислення.

Для формування творчих здібностей у старших дошкільників ми рекомендуємо вихователям програму дій у навчально-виховному процесі:

- введення у програму спеціальних занять, спрямованих на розвиток творчих здібностей, творчої уяви, творчого мислення дітей старшого дошкільного віку;

- на організованих спеціальних заняттях 3 логіко-математичного розвитку, мовленнєвого розвитку, малювання, художньої праці, музики, танців, ознайомлення з природних середовищем застосовувати завдання творчого характеру;

- скерування предметних, сюжетно-рольових, інсценізаційних ігор старших дошкільників на розвиток творчих здібностей;

- використання інтегрованих спеціальних завдань та ігор для розвитку творчих здібностей старших дошкільників;

- робота з батьками та педагогами, самовдосконалення вихователів.

Ми пропонували вихователям у межах технічно-розвивального, художньо-розвивального та предметно-естетичного середовища організовувати предметні зони, в яких мають міститися матеріали з певного творчого напряму. Дитина має право сама вибирати, 3 яким матеріалом вона хоче працювати. У зоні математики мають міститися матеріали, що розвивають уявлення дитини про цифри, просту лічбу, дроби та елементарні математичні дії. Наприклад, матеріал-гра "Весела лічба": картинки 3 певною кількістю якихось предметів (зайчики, м'ячики, машинки) і відповідна цифра внизу, під малюнком. У роботі з такими картками дитина обводить пальцем цифру, при цьому проговорює іiі (перші рази назву цифри озвучує вихователь). Така математична гра спрямована на розвиток зорової, тактильної, і слухової пам'яті, творчого поєднання предметів у множини, творче розповідання за картинкою тощо. Також у математичній зоні мають міститися матеріали, які сприятимуть розвитку в дітей старшого дошкільного віку понять пори року, про частини доби, про вагу, зріст тощо.

У зоні математики також можна розмістити гру “Частини і дроби”, завдяки якій старші дошкільники можуть навчитися вільно оперувати такими поняттями, як 1/2 і 1/6. Для цього можна розмістити кольорові дерев'яні або пластмасові кружечки, поділені на частини, може також бути розміщений об'ємний круг (наприклад у вигляді торта), що складається із об'ємних картонних кусків. Діти, освоюючи цю гру, матимуть змогу вільно орієнтуватися в дробах на рівні другого класу загальноосвітньої школи.

Для розвитку просторового уявлення старших дошкільників у зоні математики можна розмістити різні об'ємні геометричні фігури, основами яких є відомі старшим дошкільникам плоскі фігури - прямокутники, трикутники, квадрати, ромби, п'ятикутники тощо i прослідковувати, яким чином із плоских фігур можна утворити об'ємні фігури.

У зоні мовленнєвого розвитку та підготовки до письма можуть міститися матеріали 3 розвитку пам'яті, уяви і мислення, наприклад матеріали “Інтуїтивне читання”. Ця гра складається 3 двох етапів. 1 етап - дитина отримує картинку з написом під зображенням. До неї додається декілька карток зі словами. Дитина повинна знайти серед карток слово, що відповідає напису на картинці. На 2-му етапі дитина отримує картинки без підписів і повинна по пам'яті знайти картинку з назвою зображеного предмета. В результаті інтуїтивного читання з пізнавальними елементами відбувається розширення словникового запасу дитини. У цій зоні також містяться матеріали з упорядкування розповіді за картинками.

У науковій зоні можна розмістити колекції рідкісних комах (метеликів, жуків, скорпіонів, інших комах), зразки різних камінців, інших природних матеріалів, вугілля, пластмасу, різні види тканин тощо, колекція кори дерев, адже таким чином діти старшого дошкільного віку не тільки зможуть споглядати на ці предмети, а й вивчати їх тактильним способом.

Серед засобів розвитку творчих здібностей ми рекомендували вихователям використовувати гру, 
активізацію старших дошкільників у творчому розповіданні, сприйнятті, продовжуванні та придумуванні дошкільниками казок, використання творчих завдань, творче вираження старших дошкільників в образотворчому, музичному, хореографічному мистецтві та драматизації. В цьому випадку збагачення освітнього процесу творчо розвиваючими формами діяльності забезпечуватиме створення стійкого фундаменту розвитку у дітей старшого дошкільного віку творчих здібностей і готовності до навчання в початковій школі.

Ми рекомендували вихователям кожне заняття проводити в напрямку розвитку творчих здібностей дітей дошкільного віку, де гармонійно поєднувати форму і зміст, сюжет і композиція, методи i прийоми, які допомагатимуть створювати креативний простір для спілкування, сприятимуть розвитку асоціативного мислення, імпровізації, фантазії, реалізації власних задумів.

Педагогічними інструментами для реалізації завдань з упровадження технології розвитку творчих здібностей дітей нами визначено наступні форми занять: заняття-фантазія, заняття-гра, заняття-подорож, заняття-дослідження, заняттяказка, заняття-зустріч, заняття-пригода, заняттясвято тощо.

Також для розвитку творчих здібностей ми рекомендували використовувати репродуктивні, інформаційно-рецептивні, ігрові, пошукові методи та прийоми.

Для актуалізації асоціативних зв'язків для формування творчих здібностей у дітей старшого дошкільного віку ми рекомендували вихователям використовувати певні завдання, використовуючи засоби мистецтва, зокрема:

1. До прослуханих звуків природи (злива, шум океану, нічна серенада солов'я тощо) підбирали представлені твори мистецтва (наприклад, В. Косенко “Дощик”, І. Левітан “Вечір”, М. Сингаївський “Лугова казка”, П. Тичина “Хор лісових дзвіночків" тощо).

2. Із запропонованого списку мистецьких творів вибирали ті, що відображають естетичні враження після хвилинки милування природи (наприклад, хвилинка милування: “Наш красень дубок” - Н. Забіла “Під дубом зеленим”, А. Куїнджі “Дуби”, І. Шишкін “Дубовий ліс в сірий день”, Г. Тютюнник "Навіщо дубам листя взимку"; О. Шовкуненко “Дуби” тощо.

3. Старші дошкільники за консультацією вихователів малювали кольорову палітру до певного літературного твору та пояснювали власний вибір (наприклад, М. Познанська “Сонячна сопілка”, Л. Костенко “Березовий листок”, В. Заєць “Шипшинові ліхтарі”, Д. Павличко "Вітер" тощо).

4. Діти старшого дошкільного віку придумували якомога більше назв до запропонованих педагогами творів мистецтва (наприклад, М. Приймаченко "Казковий звір", В. Васнєцов “Спляча красуня", А. Гедіке "Гроза", В. Костанді “Сіра хмара"; Б. Фільц “Весняний дзвін” тощо).

5. Старші дошкільники колективно продовжували казку за запропонованою вихователем або іншого мистецького твору. Таким чином, вихованці зможуть накопичувати та званий “Асоціативний мистецький портфель”, пізніше педагогам можна проводити гру “Відгадай твір за знаком-образом”.

6. Дошкільники також відгадували казку за запропонованим вихователем описом певного героя або описом певних предметів, побутових предметів, описом природи із певної казки.

6. Діти старшого дошкільного віку придумували якомога більше метафор до об'єктів, зображених на певній картині. Наприклад, камінь самотній сторож, зачарований герой; корабель - острівець життя, самотній мандрівник, чорний розвідник; пташка фея-чарівниця, провісниця весни, лікар дерев; крига - заморожена природа, царство холоду, білий морок тощо.

Ми рекомендуємо вихователям для формування творчих здібностей у старших дошкільників розвивати у них активне творче ставлення також до літературно-мовного матеріалу, використання ігор-фантазувань, вправ, завдань, залучення дошкільників до складання віршиків, коротеньких римовок, стимулювати прислухалися до вдалих висловів інших дітей, дорослих, урізноманітнювати роботу з казкою (читання, розповідання, малювання, інсценізація, придумування дошкільниками казок, фантазування дошкільниками творчого сюжету, придумування дітьми дошкільного віку логічного перебігу подій у казці, імпровізування та відтворення голосів, рухів казкових персонажів, введення нових героїв, зміна характерів героїв, переставляння героїв та сюжетів із різних казок, придумування кінця казки, складання казки за схемою тощо), інтегрувати заняття різними видами діяльності старших дошкільників для стимулювання їх творчих здібностей, наприклад, закріплювати художні, музичні, танцювальні композицій та драматизацію у різних ситуаціях (на заняттях, на зарядці, між заняттями, на прогулянці тощо).

Висновки. Проведене нами дослідження дозволяє стверджувати, що формування творчих здібностей дітей старшого дошкільного віку має включатися в усі види творчої діяльності: ігри, спрямовані на розвиток фантазії, уяви як 
універсальних властивостей особистості дошкільника; творчі завдання, проведення ігор, спрямовані на розвиток творчих здібностей та вмінь на заняттях 3 різних видів мистецтв (малювання, аплікація, ліплення, танці, драматизація тощо); творчі завдання на заняттях з логіко-математичного та мовленнєвого розвитку та ознайомлення з природним довкіллям з дітьми старшого дошкільного віку; завдання тестової діагностики творчих потенційних можливостей старших дошкільників; ігрові форми проведення фізкультхвилинок та “пальчикових ігор”, хвилинок фантазування; проведення ігор та застосування творчих завдань на прогулянках, екскурсіях; творчі завдання, ділові ігри та тренінги для групових та індивідуальних занять з батьками та педагогами.

\section{ЛІТЕРАТУРА}

1. Колісник-Гуменюк Ю. Формування та розвиток творчості у майбутніх фахівців ПТНЗ художнього профілю. Молодь і ринок. №8(127). 2015. С.70-73.

2. Коментар до Базового компонента дошкільної освіти в Україні: Наук.-метод. Посібник. Наук. ред. О.Л.Кононко. К.: Ред. журн. “Дошкільне виховання”, 2003. $243 \mathrm{c}$.

3. Сисоєва С. О. Основи педагогічної творчості : підручник. Київ, 2006. 344 с.

4. Шандрук С. Творчість як употужнення здібностей особистості. Психологія. 2015. №3. С.86-91.

\section{REFERENCES}

1. Kolisnyk-Humeniuk, Yu. (2015). Formuvannia ta rozvytok tvorchosti u maibutnikh fakhivtsiv PTNZ khudozhnoho profiliu [Formation and development of creativity in future specialists of art profession]. Youth and market, No. 8(127), pp.70 73. [in Ukrainian].

2. Komentar do Bazovoho komponenta doshkilnoi osvity v Ukraini (2003). [Commentary on the Basic Component of Preschool Education in Ukraine]. (Ed.). O.L.Kononko. Kyiv, p.243. [in Ukrainian].

3. Sysoyeva, S. O. (2006). Osnovy pedahohichnoi tvorchosti : pidruchnyk [Fundamentals of pedagogical creativity: a textbook]. Kyiv, p.344. [in Ukrainian].

4. Shandruk, S.(2015). Tvorchist yak upotuzhnennia zdibnostei osobystosti [Creativity as a reinforcement of personality abilities]. Psychology, no.3, pp.86 91. [in Ukrainian].

Стаття надійшла до редакції 27.09.2019

УДК 378.011.3-051:796

DOI:

Соломія Ілляш, кандидат психологічних наук, доиент кафедри педагогіки та методики початкової освіти Дрогобииького державного педагогічного університету імені Івана Франка Людмила Савченко, кандидат педагогічних наук, старший викладач кафедри теорії та методики дошкільної освіти Комунального закладу “Харківська гуманітарно-педагогічна академія” Харківської обласної ради

\section{ПІДГОТОВКА МАЙБУТНІХ УЧИТЕЛІВ ПОЧАТКОВОӤ ШКОЛИ ДО ОРГАНІЗАЦІЇ СПОРТИВНО-ОЗДОРОВЧОӤ ДІЯЛЬНОСТІ}

У статті з 'ясовано теоретичні засади підготовки майбутніх учителів початкової иколи до організації спортивно-оздоровчої діяльності; охарактеризовано їі особливості; проаналізовано наукові джерела 3 досліджуваної проблеми; уточнено зміст поняття “спортивно-оздоровча діяльність” та суміжних термінів; а також виокремлено педагогічні умови, що сприяють підвищенню професійної підготовки майбутніх учителів початкової иколи до спортивно-оздоровчої діяльності.

Ключові слова: спортивно-оздоровча діяльність; фізичне виховання; спортивне виховання; спортивномасова робота; початкова школа; майбутні вчителі.

Jim. 9.

Solomiya Illyash, Ph.D.(Psychology), Associate Professor of the Pedagogy and Methodology of Primary Education Department Drohobych Ivan Franko State Pedagogical University Liudmyla Savchenko, Ph.D. (Pedagogy), Senior Lecturer, Department of Theory and Methods of Preschool Education Municipal Establishment "Kharkiv Humanitarian Pedagogical Academy" of Kharkiv Regional Council

\section{TRAINING OF FUTURE TEACHERS OF PRIMARY SCHOOL FOR THE ORGANIZATION OF SPORTS AND HEALTHY ACTIVITY}

The article reveals the theoretical principles of training of future teachers of primary school for the organization of sports and healthy activitiy; its features are characterized; scientific sources on the studied problem 